\title{
The desert at Zait Bay, Egypt: a bird migration bottleneck of global importance
}

\author{
GUDRUN HILGERLOH
}

\section{Summary}

The study area at Zait Bay, Egypt $\left(c .700 \mathrm{~km}^{2}\right)$ is situated in the middle of the West Asian-East African migration flyway used by very large numbers of soaring migrants. At this site the corridor narrows into a bottleneck. There exist only very few bottlenecks of this magnitude in the world. Observations were performed at all hours between sunrise and sunset at 26 observation sites, situated $5 \mathrm{~km}$ apart. The northern part of the area under investigation (19 observation sites) was situated within the Gebel El Zeit IBA (criteria AI and A4iv), while the southernmost part ( 8 observation sites) was outside. The overall evaluation has shown that 179,681 soaring birds including 122,454 storks and 36,976 raptors were observed in total. Within a radius of $2.5 \mathrm{~km}$ from each observation site 97,143 soaring birds including 59,308 storks and 30,489 raptors were observed during the 604 hours of observation. Eleven species were recorded in numbers that exceed $1 \%$ of their flyway populations. Of special concern regarding bird conservation are those birds resting or flying in the first $200 \mathrm{~m}$ of elevation. In total 6,624 soaring birds were seen resting $(2,252$ within a radius of $2.5 \mathrm{~km})$. Thirty-three percent of the storks and $47 \%$ of the raptors were observed resting or flying at heights within the lowest $200 \mathrm{~m}$. The median height of flying birds varied between $5 \mathrm{~m}$ (harriers) and $500 \mathrm{~m}$ (Common Crane Grus grus). According to the raw data, criteria for nomination of the area as an IBA (20,000 raptors and storks in one migration season, globally threatened species) were fully met outside the existing IBA. Also, to the south of the study area, very high numbers of migrants were confirmed by spontaneous, non-systematic observations. Accordingly, a change of the boundaries is suggested. The regional analysis, based on extrapolations, has to be regarded as a preliminary study. The analysis failed to show a geographical trend for any single species. The data from this study establish a high concentration of gliding and soaring birds in the study area, within and adjacent to the already designated IBA.

\section{Introduction}

Soaring birds are almost entirely dependent on updrafts to sustain their migration flight. This dictates and vastly reduces their choice of migration routes and funnels them along very narrow migration 'corridors'. The lack of updrafts over large bodies of water prevents them from crossing seas except at the narrowest of straits. Among the best-known of these are the Straits of Gibraltar, the Bosporus and Bab-el-Mandeb (Newton 2008). Many of the birds migrating to and from East Africa even avoid crossing the Gulf of Suez and detour via Suez instead. However, others migrating to Sinai in spring concentrate at Zait Bay as it is the narrowest crossing point in the southern part of the Gulf of Suez.

Globally threatened species such as Egyptian Vulture Neophron percnopterus ('Endangered'), Lesser Kestrel Falco naumanni ('Vulnerable'), Greater Spotted Eagle Aquila clanga ('Vulnerable'), and Eastern Imperial Eagle Aquila heliaca ('Vulnerable'), and the 'Near threatened' Pallid 
Harrier Circus macrourus are known to migrate through this area. The most numerous species is reported to be Levant Sparrowhawk Accipiter brevipes and White Stork Ciconia ciconia (Baha El Din 1999). In the space of a very few days the entire world population of Levant Sparrowhawks migrate through this area, usually in huge flocks (Baha El Din 1999). The main route of White Storks migrating along the eastern flyway passes through the area of Zait Bay (Schulz 1988, Berthold et al. 2001). Ornithologists have not been slow to recognise the area's importance (Grieve 1996, Baha El Din 1999, Christensen and Jensen 2002, Tammens 2008). BirdLife International has acknowledged the great relevance of the Zait Bay area for soaring and gliding migrants and has designated an Important Bird Area (IBA), Gebel El Zeit, (criterion AI globally threatened species, and a bottleneck of global importance (criterion A4iv - more than 20,000 raptors and storks or cranes in one of the two migration seasons).

In the current study, initial systematic observations have been carried out in the desert next to Zait Bay in order to present a quantitatively supported general evaluation of the global significance of the site. Special attention needs to be paid to resting and low-flying birds as these are more endangered by constructions such as wind turbines standing in their path.

The fact that the northern part of the study area is situated within the Gebel El Zeit IBA and the southernmost part outside, presents an occasion to re-examine the present boundaries of the IBA and to make suggestions for changes if necessary.

\section{Methods}

\section{Study area}

This study was made to assess the risks to migratory soaring birds from wind farms. The study area is situated in the coastal desert west of Zait Bay and west of the main Suez-Hurghada road in Egypt (Figure 1). It is bordered on the west by the foothills of the Red Sea Mountains and on the east by plains stretching to the foothills of the mountain chain of Gebel El Zeit, with hills up to $460 \mathrm{~m}$ high rising directly out of the Red Sea. Except for a salt depression (sabkha) in the north, the study area consists entirely of dry desert. The northernmost 18 observation sites are situated within the Gebel El Zeit IBA, the southernmost eight sites outside it.

\section{Bird species}

The area supports only a few permanent or seasonal resident bird species, the chief of which are sandgrouse (mainly Spotted Sandgrouse Pterocles senegallus), along with Brown-necked Raven Corvus ruficollis, a few Bar-tailed Desert Larks Ammomanes cincturus, Hoopoe Larks Alaemon alaudipes and Pale Crag Martins Ptyonoprogne fuligula. On the other hand, it is visited twice a year by staggering numbers of birds on migration. The majority of these belong to soaring and gliding species such as storks and raptors that migrate during the day. Other day-migrating species recorded during the project were cormorants, waders and small birds, mainly passerines.

\section{Standardised daytime field observations}

A row of thirteen observation sites $5 \mathrm{~km}$ apart from each other was established in the central part of the western desert. Five kilometres further east, a second row of 13 observation points - also $5 \mathrm{~km}$ apart - was set up along the road running through the eastern part of the study area (Figure $\mathrm{I}$, See Supplementary materials 1 ).

Given an observation radius from each observation point of $2.5 \mathrm{~km}$, this created a double row of 13 observation circles of $19.6 \mathrm{~km}^{2}$ succeeding one another from south to north. The observations were made from February 20 to May 6 2007. Site 1 of the road row was re-sited to coincide with the nearby radar site of the project. The observations were performed by ornithologists with more than five years experience in bird identification. 


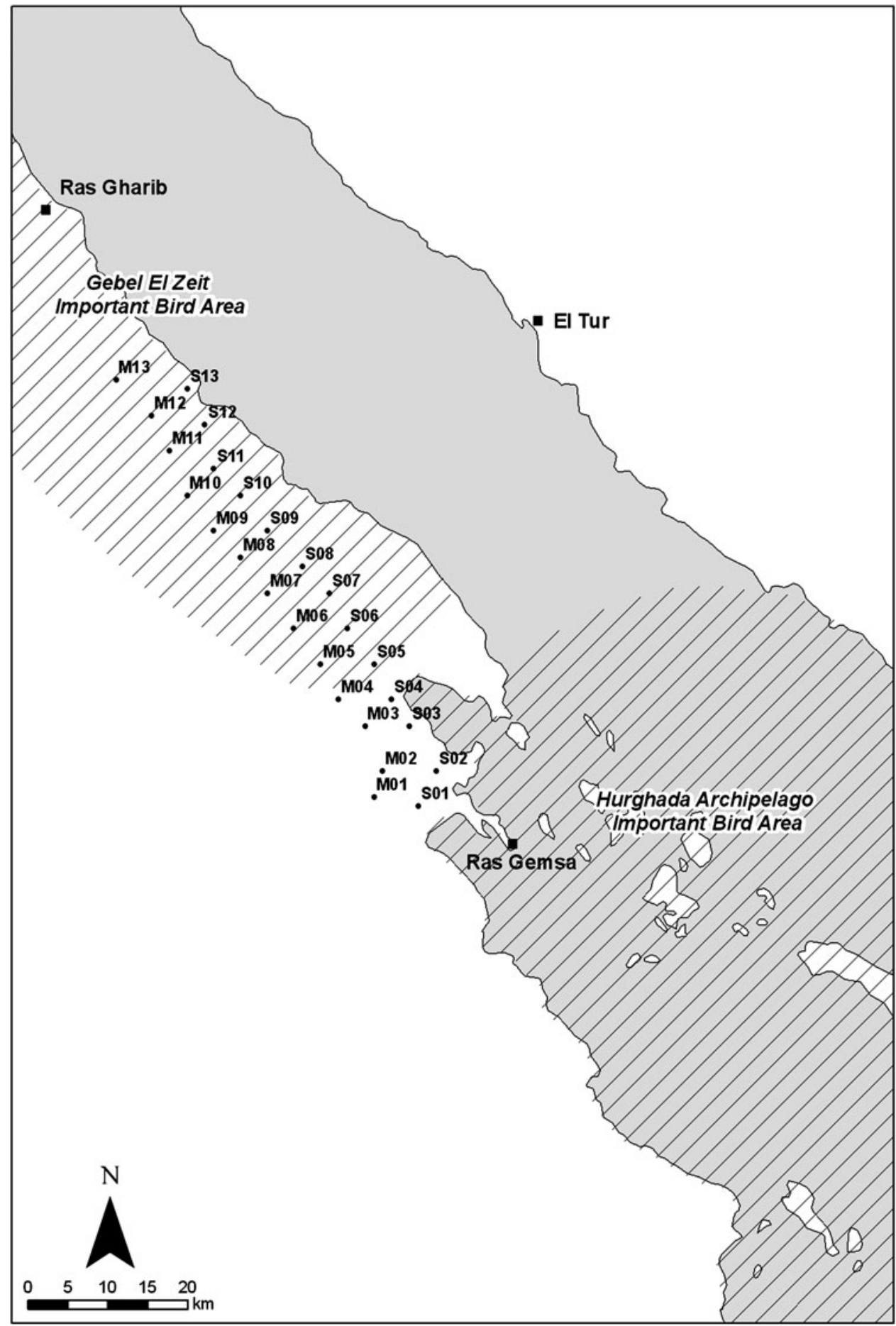

Figure 1. Position of the observation sites $\mathrm{M}_{1-13}$ and $\mathrm{S}_{1-13}$ and of the IBAs 'Gebel El Zeit' and 'Hurghada Archipelago' (produced by BirdLife International based on IBA information in the World Bird Database and information supplied by the author). 
Two observation teams, each consisting of two persons, were formed and a rotation schedule was set up according to which all the sites were visited at all hours between sunrise (05ho7 to o6h3o) and sunset (17h45 to $18 \mathrm{~h}_{35}$ ), each site being visited every third day. One team worked from sunrise to noon, the other from noon to sunset. Observation periods were principally of 60 minutes per site and 11 hours per day. Deviations from the work plan were caused by sand storms and by the occasional illness or unreliability of locally hired drivers. The study area was under observation for a total of 604.4 hours. Each of the sites received on average 23 visits by alternate teams.

The first team started observations at the south of the central corridor (Mi) and continued at the subsequent sites northwards ( $\mathrm{M}_{2}, \mathrm{M}_{3}$ and so on). The second team started observations at the road-sites in the north $\left(\mathrm{S}_{13}\right)$ and continued visiting the sites southwards ( $\mathrm{S}_{12}$, $\mathrm{S}_{11}$ and so on). Each team searched the sky for birds using binoculars of $10 \mathrm{x} 40$ magnification. For detailed identification, telescopes with magnifications from $20 \mathrm{x}$ to $60 \mathrm{x}$ were used. The following parameters were determined and documented: start of observation at a site, end of observation, exact time of observation, species, number of birds, flight direction, flight height of the birds, distance from observer, direction from observer, fibrillation border $(\mathrm{m})$, visibility $(\mathrm{km})$, cloud cover $(\%)$, type of cloud, wind direction, wind strength (Beaufort scale).

Estimations of the flight height and distances of the birds were calibrated with the help of laser binoculars (Geovid 10 x 40 and 7 x 40 magnification) and by comparisons with radar readings. Distances over $\mathrm{I} \mathrm{km}$ from the observer were calibrated by reference to distances to topographical features measured by means of GPS. With large aggregations of birds the height of the lower margin of the flock was recorded. During the first weeks, the composition of teams was changed regularly in order to achieve standardised procedures and minimise differences among individual observers and between teams. The data contain a margin of error, as parameters such as migration height, distance, number of birds in large flocks and population sizes are not measured but estimated.

\section{Radar observations}

Radar observations were performed using a $25 \mathrm{KW}$ Furuno ship radar. It was situated close to the southern border of the concessionary area $\left(27.69^{\circ} \mathrm{N}, 033.49^{\circ} \mathrm{E}\right)$. The radar was fixed on a stand permitting manual adjustment of the rotation plane. The radar beam rotated vertically in order to evaluate the height of birds.

\section{Evaluation of daytime observations}

Evaluation of the raw data was performed at three levels. The first evaluation ignored the distance at which birds were recorded. Then, in order to assign the birds to a specific area and in order to standardise the conditions of species recognition, subsequent evaluations took account only of birds recorded within $2.5 \mathrm{~km}$ of the observer. At greater distances, some of the species can no longer be identified safely.

Centred on each observation site was a circular reference area of $2.5 \mathrm{~km}$ radius. All birds crossing this area were recorded once. In a further evaluation, the height of migrating birds was taken into consideration. Birds present in the first $200 \mathrm{~m}$ were considered separately. The height distribution of the birds was evaluated within a radius of $2.5 \mathrm{~km}$ from the observer.

The estimate of the number of birds migrating through the different parts of the study area throughout the migration season was achieved by means of extrapolations. These are very rough approximations, subject to several uncertainties, but they do compensate to some extent for the lack of manpower for more hours of observation.

In order to assess the regional distribution of migrants for each species and site, the percentage of the flyway population was calculated and $1 \%$ taken as a general measure of global importance. 
Three parameters were required: the number of birds per hour, the number of birds per season and the size of the flyway population.

The dates of the first and last daytime sightings of a species in each migration season are taken as indicators of the daily presence and the limits of the migration period of the species in this area. The number (median, range) of birds per hour during the migration period of the species and during its daily hours of presence was calculated (See Supplementary materials 2). In a few cases where the observation lasted less than 60 minutes, the number per hour was extrapolated. The estimation of the number of birds per observation season was extrapolated from the mean migration frequency (total number of birds per total number of hours within the hours and days of presence of a species at a site) (See Supplementary materials 3).

The number of days with the central $90 \%$ of the passage of a species was used in the extrapolation of the birds per season in order to keep the estimates conservative (See Supplementary materials 4 ).

Except in the cases of storks and cranes, the number of hours of active migration in general was similar to that during which resting birds of a species were seen. In order to keep the extrapolations conservative, for most species a presence of nine hours was taken, for Black Kite Milvus migrans 10 and for harriers II (See Supplementary materials 2). In contrast, whereas storks were seen migrating throughout 10.5 hours, they were observed resting during seven hours only. Consequently, for the daily hours of presence, a general value of eight hours was taken. On the same principle, the same value was taken for the Common Crane Grus grus (with 8.5 hours seen resting and to hours seen in flight).

\section{Estimating flyway populations}

For soaring species migrating on a narrow front it is possible to make counts of the flyway population. The birds migrating through the study area also pass through Israel, where numerous such counts have been performed. The maximum numbers emerging from these counts were used as a basis for the population estimates in this study (Leshem and Yom-Tov 1996, Shirihai 1996, Shirihai et al. 2000). However, where the breeding population of birds migrating north along the east African flyway exceeded the flyway population counts from Israel, the former - higher - figures were taken as the flyway population size. However, there was one exception: the flyway population of Common Cranes was estimated at 5,000-10,000 individuals in Israel (Shirihai 1996), whereas we saw more than 30,000 at Zait Bay. In view of this a flyway population of 50,000 birds is certainly more accurate (Appendix 1 ). Flyway population sizes for species migrating on a broad front on this flyway are not available.

\section{Results}

\section{Magnitude of migration}

Soaring and gliding birds were present in the form of pelicans, herons, egrets, storks, cranes, beeeaters and raptors (Table 1 ).

In total, 179,681 soaring birds, including 122,454 storks and 36,976 raptors were observed during systematic observations between February 20 and May 62007 (Table 1). White Stork was the most numerous species, followed by Steppe Buzzard Buteo buteo vulpinus, Common Crane and Levant Sparrowhawk (Table 1).

Within a radius of $2.5 \mathrm{~km}$ of the observers, 97,143 soaring birds including 59,308 storks and 30,489 raptors were identified (Table 1 ). 44,835 storks and 23,052 raptors were observed within and 14,473 storks and 7,437 raptors outside of the existing IBA (Figure 1). In the first $200 \mathrm{~m} \mathrm{19,355}$ storks and 14,297 raptors were observed during systematic counts (Table 2). In total, 14,937 storks and 11,099 raptors were observed inside the existing IBA and 6,073 storks and 3,492 raptors outside. Thus, inside and outside the IBA, $47-48 \%$ of the raptors were identified in the first $200 m$. Thirtythree percent of the storks were flying inside the IBA and $42 \%$ outside. 
Table 1 . Number of resting and flying birds of soaring and gliding species at all distances and at distances up to $2.5 \mathrm{~km}$ in the desert of Zait Bay from February 20 to May 62007.

\begin{tabular}{|c|c|c|}
\hline Species & All distances Total & Radius $2.5 \mathrm{~km}$ Tota \\
\hline Great White Pelican Pelecanus onocrotalus & 1,801 & 882 \\
\hline Cattle Egret Bubulcus ibis & 1 & 1 \\
\hline Squacco Heron Ardeola ralloides & 6 & 6 \\
\hline Western Reef Heron Egretta gularis & 82 & 82 \\
\hline Purple Heron Ardea purpurea & 9 & 9 \\
\hline Egret species Egretta sp. & 3 & 3 \\
\hline White Stork Ciconia ciconia & 120,745 & 58,063 \\
\hline Black Stork Ciconia nigra & 1,709 & 1,245 \\
\hline Stork species Ciconia sp. & 273 & \\
\hline Greater Flamingo Phoenicopterus ruber & 25 & 25 \\
\hline Black Kite Milvus migrans & 1,660 & 1,366 \\
\hline Egyptian Vulture Neophron percnopterus & 64 & 60 \\
\hline Montagu's Harrier Circus pygargus & 12 & 12 \\
\hline Pallid Harrier Circus macrourus & 13 & 13 \\
\hline $\begin{array}{l}\text { Pallid Harrier/Montagu's Harrier C. macrourus/ } \\
\text { C. pygargus }\end{array}$ & 12 & 11 \\
\hline Western Marsh Harrier Circus aeruginosus & 62 & 60 \\
\hline Harrier species Circus sp. & 2 & 1 \\
\hline Eurasian Sparrowhawk Accipiter nisus & 76 & 73 \\
\hline Levant Sparrowhawk Accipiter brevipes & 7,600 & 6,700 \\
\hline Levant Sparrowhawk/Sparrowhawk A. nisus/A. brevipes & 6 & 6 \\
\hline Hawk species Accipiter sp. & 18 & 18 \\
\hline European Honey Buzzard Pernis apivorus & 1,381 & 1,227 \\
\hline $\begin{array}{l}\text { Steppe Buzzard or Honey Buzzard Pernis apivorus/ } \\
\text { Buteo b. vulpinus }\end{array}$ & 855 & 559 \\
\hline Steppe Buzzard Buteo buteo vulpinus & 23,539 & 17,792 \\
\hline Long-legged Buzzard Buteo rufinus & 98 & 68 \\
\hline Buzzard species Buteo sp. & 82 & 46 \\
\hline Eastern Imperial Eagle Aquila heliaca & 1 & 1 \\
\hline Steppe Eagle Aquila nipalensis & 1,747 & 1,553 \\
\hline Steppe Eagle/Tawny eagle $A$. nipalensis/rapax & 1 & 1 \\
\hline Greater Spotted Eagle Aquila clanga & 9 & 9 \\
\hline Lesser Spotted Eagle Aquila pomarina & 195 & 177 \\
\hline Aquila sp. & 669 & 364 \\
\hline Booted Eagle Hieraaetus pennatus & 118 & 115 \\
\hline Short-toed Snake-eagle Circaetus gallicus & 95 & 87 \\
\hline Osprey Pandion haliaetus & 7 & 7 \\
\hline Common Kestrel Falco tinnunculus & 53 & 53 \\
\hline Eurasian Hobby Falco subbuteo & 3 & 3 \\
\hline Lesser Kestrel Falco naumanni & 20 & 20 \\
\hline Lesser Kestrel/Kestrel F. naumanni/F. tinnunculus & 19 & 19 \\
\hline Peregrine Falcon Falco peregrinus & 3 & 3 \\
\hline Barbary Falcon Falco pelegrinoides & 2 & 2 \\
\hline Barbary Falcon/Peregrine F. pelegrinoides/ & 2 & 2 \\
\hline \multicolumn{3}{|l|}{ F. peregrinus } \\
\hline Lanner Falcon Falco biarmicus & 2 & 2 \\
\hline Falcon species Falco sp. & 2 & 2 \\
\hline Raptor spec. Accipitriformes & 583 & 57 \\
\hline Common Crane Grus grus & 15,906 & 6,228 \\
\hline European Bee-eater Merops apiaster & 60 & 60 \\
\hline Blue-cheeked Bee-eater Merops persicus & 10 & 10 \\
\hline Bee-eater species Merops sp. & 40 & 40 \\
\hline Total & 179,681 & 97,143 \\
\hline
\end{tabular}


Table 2. Number of resting birds, number of birds present in the first $100 \mathrm{~m}$ of height (including resting birds), in the second $100 \mathrm{~m}$ and above $200 \mathrm{~m}$. The observations were performed in the desert of Zait Bay in the time period between February 20 and May 62007 within a radius of $2.5 \mathrm{~km}$ from each site.

\begin{tabular}{|c|c|c|c|c|c|}
\hline Species & Resting & $<101$ & $101-200$ & $>200$ & Total \\
\hline Great White Pelican & 53 & 724 & 76 & 29 & 882 \\
\hline Cattle Egret & & 1 & & & 1 \\
\hline Squacco Heron & 6 & & & & 6 \\
\hline Western Reef heron & 82 & & & & 82 \\
\hline Purple Heron & & 9 & & & 9 \\
\hline Egret sp. & 3 & & & & 3 \\
\hline White Stork & 1,656 & 8,981 & 9,817 & 37,609 & 58,063 \\
\hline Black Stork & 31 & 218 & 327 & 669 & 1,245 \\
\hline Greater Flamingo & 25 & & & & 25 \\
\hline Black Kite & 16 & 778 & 203 & 369 & 1,366 \\
\hline Egyptian Vulture & & 12 & 3 & 45 & 60 \\
\hline Montagu's Harrier & & 11 & 1 & & 12 \\
\hline Pallid Harrier & & 13 & & & 13 \\
\hline Pallid Harrier/Montagu's Harrier & 1 & 8 & & 2 & 11 \\
\hline Western Marsh Harrier & 4 & 50 & 2 & 4 & 60 \\
\hline Harrier sp. & & 1 & & & 1 \\
\hline Eurasian Sparrowhawk & & 54 & 5 & 14 & 73 \\
\hline Levant Sparrowhawk & & 25 & 2,574 & 4,101 & 6,700 \\
\hline Levant Sparrowhawk/Sparrowhawk & & 5 & & 1 & 6 \\
\hline Hawk undetermined & & 11 & 1 & 6 & 18 \\
\hline Europian Honey Buzzard & & 401 & 244 & 582 & 1,227 \\
\hline Steppe Buzzard or Honey Buzzard & & 227 & 84 & 248 & 559 \\
\hline Steppe Buzzard & 143 & 5,850 & 3,213 & 8,586 & 17,792 \\
\hline Long-legged Buzzard & & 21 & 9 & 38 & 68 \\
\hline Buzzard sp. & 1 & 12 & 5 & 28 & 46 \\
\hline Eastern Imperial Eagle & & & & 1 & 1 \\
\hline Steppe Eagle & 3 & 63 & 189 & 1,298 & 1,553 \\
\hline Steppe Eagle/Tawny Eagle & & & & 1 & 1 \\
\hline Greater Spotted Eagle & & 1 & & 8 & 9 \\
\hline Lesser Spotted Eagle & & 18 & 24 & 135 & 177 \\
\hline Aquila sp. & 6 & 53 & 34 & 271 & 364 \\
\hline Booted Eagle & & 20 & 15 & 80 & 115 \\
\hline Short-toed Snake-Eagle & 1 & 18 & 10 & 58 & 87 \\
\hline Osprey & 1 & 3 & 1 & 2 & 7 \\
\hline Common Kestrel & 9 & 42 & 1 & 1 & 53 \\
\hline Eurasian Hobby & & 2 & 1 & & 3 \\
\hline Lesser Kestrel & & 16 & 3 & 1 & 20 \\
\hline Lesser Kestrel/Kestrel & & 19 & & & 19 \\
\hline Peregrine Falcon & & 2 & & 1 & 3 \\
\hline Barbary Falcon & & & 2 & & 2 \\
\hline Barbary Falcon/Peregrine & & 2 & & & 2 \\
\hline Lanner Falcon & & 2 & & & 2 \\
\hline Falcon sp. & & 1 & & 1 & 2 \\
\hline Raptor sp. & & 9 & 32 & 16 & 57 \\
\hline Common Crane & 204 & 1,109 & 310 & 4,605 & 6,228 \\
\hline European Bee-eater & 7 & 53 & & & 60 \\
\hline Blue-cheeked Bee-eater & & & & 10 & 10 \\
\hline Bee-eater sp. & & 40 & & & 40 \\
\hline Total & 2,252 & 18,885 & 17,186 & 58,820 & 97,143 \\
\hline
\end{tabular}




\section{Percentage of the flyway population}

One percent of the flyway population is taken as a general measure of global importance. Regardless of the kind of counts recorded - those ignoring the distance at which birds were recorded or those considering only birds observed within the range of $2.5 \mathrm{~km}$ - there were 11 species whose recorded numbers were in excess of $1 \%$ of their flyway population. For seven of these, this still applies if one considers only the birds flying at or below $200 \mathrm{~m}$, and for as many as five of these again when counting only those at or below $100 \mathrm{~m}$ (Table 3). White Stork, Common Crane and Levant Sparrowhawk were present with the highest percentage of the flyway population. Storks can be recognized at up to $12 \mathrm{~km}$ distance, which explains the high percentage of storks seen during the systematic observations irrespective of distance.

\section{Resting birds}

Whether birds use an area for resting is essential to the evaluation of the risks to birds at this site. Disregarding the distance of the birds from the observer, 6,624 soaring birds were observed resting, of which 2,252 were within $2.5 \mathrm{~km}$ (Table 2). In total, $0.6 \%$ of the raptors and $2.8 \%$ of the storks observed within the range of $2.5 \mathrm{~km}$ were resting (Table 2). Among the resting birds White Stork, Common Crane and Steppe Buzzard were the most frequent species (Supplementary material 5). A high proportion of the storks and cranes were resting outside the IBA $-49 \%$ and $66 \%$ respectively. Pelicans, herons and flamingos were only seen in the vicinity of $\mathrm{S}_{13}$ with its salt lake situated in the salt flats.

\section{Altitude of migrating birds}

Twelve of the 21 soaring and gliding species studied migrated at median heights between 200 and $500 \mathrm{~m}$, and nine species at median heights below $100 \mathrm{~m}$ (Table 4). The low-flying species were Great White Pelican Pelecanus onocrotalus, Black Kite, Pallid Harrier, Montagu's Harrier Circus pygargus, Western Marsh Harrier Circus aeruginosus, Eurasian Sparrowhawk Accipiter nisus, Common Kestrel Falco tinnunculus, Lesser Kestrel and European Bee-eater Merops apiaster.

Table 3. Percentage of the flyway population: all birds observed at any distance and height, birds observed within a radius of $2.5 \mathrm{~km}$ and birds in the first $200 \mathrm{~m}$ or in the first $100 \mathrm{~m}$ within a radius of $2.5 \mathrm{~km}$. Observations were performed in the desert at Zait Bay during the period between February 20 and May 6 2007. Only species present in numbers exceeding $1 \%$ of the flyway population are included. Population estimates see Appendix.

\begin{tabular}{|c|c|c|c|c|}
\hline Species & $\begin{array}{l}\text { All } \\
\text { distances }\end{array}$ & $\begin{array}{l}\text { Radius } \\
2.5 \mathrm{~km}\end{array}$ & $\begin{array}{l}\text { Radius } \\
2.5 \mathrm{~km}, \\
<201 \mathrm{~m}\end{array}$ & $\begin{array}{l}\text { Radius } \\
2.5 \mathrm{~km}, \\
<\text { IOI m }\end{array}$ \\
\hline Great White Pelican & 2.3 & 1.1 & 1.1 & 1 \\
\hline White Stork & 16.1 & $7 \cdot 7$ & 2.7 & 1.4 \\
\hline Black Stork & $4 \cdot 3$ & 3.1 & 1.4 & 0.6 \\
\hline Black Kite & 4.6 & $3 \cdot 7$ & 2.8 & 2.2 \\
\hline Egyptian Vulture & 1.3 & 1.2 & 0.3 & 0.2 \\
\hline Levant Sparrowhawk & 12.7 & 11.2 & $4 \cdot 3$ & o \\
\hline Steppe Buzzard & 5.1 & 3.8 & 2.0 & 1.3 \\
\hline Long-legged Buzzard & 1.6 & 1.1 & 0.5 & 0.4 \\
\hline Steppe Eagle & 2.3 & 2.1 & 0.3 & o \\
\hline Booted Eagle & 2.4 & 2.3 & 0.7 & 0.4 \\
\hline Common Crane & 31.8 & 12.5 & $3 \cdot 3$ & 2.6 \\
\hline
\end{tabular}


Table 4. Median height, lower and upper quartile of height, range and height up to which 9o\% of the birds were observed. The observations were performed in the desert of Zait Bay in the time period between February 20 and May 62007.

\begin{tabular}{|c|c|c|c|c|c|}
\hline Species & $\begin{array}{l}\text { Median } \\
\text { height (m) }\end{array}$ & $\begin{array}{l}\text { Lower } \\
\text { quartile (m) }\end{array}$ & $\begin{array}{l}\text { Upper } \\
\text { quartile (m) }\end{array}$ & $90 \%(\mathrm{~m})$ & Range (m) \\
\hline Great White Pelican & 50 & 30 & 50 & 150 & 290 \\
\hline White Stork & 300 & 200 & 300 & 300 & 799 \\
\hline Black Stork & 300 & 150 & 400 & 400 & 890 \\
\hline Black Kite & 50 & 15 & 300 & 500 & 999 \\
\hline Egyptian Vulture & 300 & 225 & 500 & 650 & 770 \\
\hline Montagu's Harrier & 5 & 4 & 10 & 20 & 149 \\
\hline Pallid Harrier & 5 & 1 & 10 & 30 & 99 \\
\hline Western Marsh Harrier & 5 & $4 \cdot 5$ & 10 & 150 & 399 \\
\hline Eurasian Sparrowhawk & 30 & 10 & 150 & 400 & 599 \\
\hline Levant Sparrowhawk & 300 & 200 & 400 & 600 & 599 \\
\hline Honey Buzzard & 200 & 100 & 400 & 500 & 599 \\
\hline Steppe Buzzard & 200 & 100 & 400 & 500 & 1,349 \\
\hline Long-legged Buzzard & 300 & 90 & 650 & 800 & 799 \\
\hline Steppe Eagle & 400 & 300 & 500 & 650 & 999 \\
\hline Lesser Spotted Eagle & 350 & 250 & 600 & 800 & 997 \\
\hline Booted Eagle & 300 & 200 & 400 & 600 & 680 \\
\hline Short-toed Snake-Eagle & 300 & 150 & 400 & 500 & 795 \\
\hline Common Kestrel & 20 & 10 & 50 & 50 & 599 \\
\hline Lesser Kestrel & 30 & 10 & 75 & 200 & 399 \\
\hline Common Crane & 500 & 300 & 500 & 600 & 690 \\
\hline European Bee-eater & 30 & 1 & 100 & 100 & 99 \\
\hline
\end{tabular}

Species with the greatest median heights were the Common Crane, Steppe Eagle Aquila nipalensis and Lesser Spotted Eagle Aquila pomarina (500 m, $400 \mathrm{~m}$ and $350 \mathrm{~m}$ respectively).

Particular attention was paid to the extent to which soaring birds made use of the lower air layers, as the risks to low flying birds by construction of wind farms is highest. Forty percent of the soaring birds ( $=38$,ooo birds), $33 \%$ of the storks and $47 \%$ of the raptors were observed at or below $200 \mathrm{~m}$ (Table 2). Over $50 \%$ of the pelicans, harriers, kites and kestrels were observed in the first $200 \mathrm{~m}$, while large species such as Steppe Eagle, Lesser Spotted Eagle, White Stork, Black Stork Ciconia nigra and Common Crane were present with less than $30 \%$. This may in part be due to the sheer size of these species, which makes them more readily visible at greater heights, thus increasing the percentage of birds counted outside the $200 \mathrm{~m}$ layer.

\section{Regional differences of migration magnitude}

Of the 16 species considered, only for Great White Pelican was there a significant difference in migration frequency between sites (Kruskal-Wallis test $\chi^{2}=42.796, P=0.015$ ). See Supplementary materials 6 and 7 for full results including a graph on the distribution of the Great White Pelican.

Eastern Imperial Eagle, Greater Spotted Eagle, Pallid Harrier and Lesser Kestrel are broad-front migrants and accordingly not expected in high numbers. These four globally threatened or near threatened species were not concentrated in any one particular area, but distributed unevenly throughout the entire study area (Table 5). Narrow front migrants tend to be spatially more concentrated on migration, and their flyway populations are better known. Table 6 and Supplementary materials 8 and 9 demonstrate that at all sites at least one species was present in 
Table 5. The number of migrants extrapolated for the central $90 \%$ of migration at different sites in the course of the observation period of each of these globally 'threatened' and 'Near Threatened' species. The observations were performed in the desert of Zait Bay in the time period between February 20 and May 6 2007 .

\begin{tabular}{|c|c|c|c|c|}
\hline Site & Pallid Harrier & Lesser Kestrel & Greater Spotted Eagle & Sum \\
\hline Mo1 & $\mathrm{o}$ & 34 & $\mathrm{o}$ & 34 \\
\hline Mo2 & o & 36 & o & 36 \\
\hline $\mathrm{Mo3}$ & $\mathrm{o}$ & o & 46 & 46 \\
\hline Mo4 & $\mathrm{o}$ & o & o & o \\
\hline Mo5 & $\mathrm{o}$ & $\mathrm{o}$ & o & $\mathrm{o}$ \\
\hline Mo6 & $\mathrm{o}$ & 135 & o & 135 \\
\hline Mo7 & 39 & o & $\mathrm{o}$ & 39 \\
\hline Mo8 & 64 & o & o & 64 \\
\hline Mog & o & $\mathrm{o}$ & 26 & 26 \\
\hline Mio & 32 & 62 & o & 94 \\
\hline M11 & 34 & 97 & o & 131 \\
\hline M12 & o & o & 77 & 77 \\
\hline $\mathrm{M}_{13}$ & $\mathrm{o}$ & o & 68 & 68 \\
\hline So1 & 33 & 74 & 28 & 135 \\
\hline So2 & o & o & 77 & 77 \\
\hline So3 & 39 & 37 & o & 75 \\
\hline So 4 & o & 74 & o & 74 \\
\hline So5 & o & o & o & o \\
\hline So6 & o & 37 & o & 37 \\
\hline So7 & 37 & 74 & o & 110 \\
\hline So8 & o & o & o & o \\
\hline Sog & o & o & o & o \\
\hline Sio & o & o & o & o \\
\hline$S_{1 I}$ & 69 & o & o & 69 \\
\hline $\mathrm{S}_{12}$ & 69 & 41 & o & 110 \\
\hline $\mathrm{S}_{13}$ & 33 & o & o & 33 \\
\hline
\end{tabular}

numbers exceeding $1 \%$ of its flyway population, even at or below $200 \mathrm{~m}$. For the area outside the IBA on average 6.5 species per site exceeded $1 \%$ of the flyway population and inside, 5.5 species.

\section{Discussion}

The study provides evidence of a generally very substantial migration through the desert of Zait Bay, a result which is also supported by spontaneous, non-systematic observations outside the recording schedule. Threatened and 'Near Threatened' species such as Egyptian Vulture, Pallid Harrier, Lesser Kestrel, Eastern Imperial Eagle and Greater Spotted Eagle, were involved.

For observation data at different sites across the world, a comparison appears difficult in light of the very different observation efforts involved. These counts were carried out by one two-person team at a time, reducing double counts to near zero, whereas in other studies - despite efforts to minimize their effect - double counts caused by simultaneous observations at several sites with overlapping sight range remain a big problem.

It would be easy to assume that soaring migrants, constrained as they are to gain height before attempting to cross the 'updraft desert' of the Gulf, will fly high over the study area and thus be of no immediate conservation concern. The fact is, however, that migrants frequently enter the stratum of the first $200 \mathrm{~m}$, which around a large scale wind farm would constitute an area of very high risk. The large amount of low-flying and resting migrants might be caused by the birds' 
Table 6. Number of species with more than $1 \%$ of the flyway population during the central $90 \%$ of the passage. Figures are based on extrapolations (Supplementary materials 8 and 9). The observations were performed in the desert at Zait Bay in the time period between February 20 and May 62007.

\begin{tabular}{llllll}
\hline Site & All heights & First 200 m & & All heights & First 200 m \\
\hline Mo1 & 3 & 1 & So1 & 7 & 4 \\
Mo2 & 3 & 2 & So2 & 8 & 4 \\
Mo3 & 7 & 4 & So3 & 8 & 4 \\
Mo4 & 6 & 5 & So4 & 9 & 3 \\
Mo5 & 7 & 3 & So5 & 2 & 1 \\
Mo6 & 8 & 4 & So6 & 9 & 3 \\
Mo7 & 9 & 3 & So7 & 6 & 4 \\
Mo8 & 5 & 3 & So8 & 6 & 4 \\
Mo9 & 4 & 4 & So9 & 8 & 5 \\
M10 & 6 & 4 & S10 & 6 & 4 \\
M11 & 6 & S11 & 6 & 3 \\
M12 & 5 & 1 & S12 & 5 & 4 \\
M13 & 7 & 2 & S13 & 2 & 2 \\
\hline
\end{tabular}

hesitation to cross the sea in bad condition, preferring to spend another night in the area. In most species (exceptions were harriers and Common Kestrel) the flight altitude varied greatly. Altitude seemed to be more an index of weather conditions than a species trait, as already recognised in Israel on the basis of radar observations (Spaar 1995).

The turbines of a wind farm, for instance, would oblige the birds to change from gliding and soaring to energy-consuming active flight, in order to avoid collisions with the rotors. Even normal migration puts birds at considerable risk (Alerstam 1990, Wilcove 2008). This is particularly evident in spring when almost constant, strong headwinds make the desert crossing extremely arduous for the birds. What would be the consequences of additional energy expenditure to circumvent the turbines? This would certainly lead to an increase in fatal casualties. They may not occur at the site of the wind farm itself, but later, further along the migration route, wherever the remaining strength of individual birds finally fails them.

Further, in spring, birds are under great time pressure, as they have to arrive at their summer quarters early enough to compete successfully for a suitable breeding site so that they are able to rear their young before leaving again for Africa. Birds arriving too late or too exhausted will not breed and reproduce successfully. Here, too, the additional energy costs incurred by circumnavigating an extensive wind farm would have a considerable negative impact. In a migration bottleneck this would involve a huge number of birds.

Fortunately there are conventions (Bern Convention, 1979) which set standards with respect to the construction of wind farms in areas such as this globally important migration bottleneck. They clearly advise against any such developments in areas that fulfil the IBA criteria (Bern Convention 1979, Hötker, et al. 2004, Langston and Pullan 2003, Drewitt and Langston 2006, Langston 2006).

Extensive, systematic surveys of birds during migration provide a solid base of data to characterize the study area as a whole. However, despite the systematic schedule of regular visits, the numbers of observation hours per site are not large enough to draw regional conclusions without extrapolations. It should be noted that they entail a considerable statistical margin of error. Only with long-term data would it be possible to describe regional characteristics reliably.

Extrapolating the number of birds per season and site is done on the assumption that observations were made at each site throughout the entire season. Since double sightings would be inevitable, it is not permissible to sum the extrapolated numbers of birds over several sites.

There was no detectable preference on the part of the migrants for any particular route through the study area. With the exception of Levant Sparrowhawk, raptors migrated predominantly 


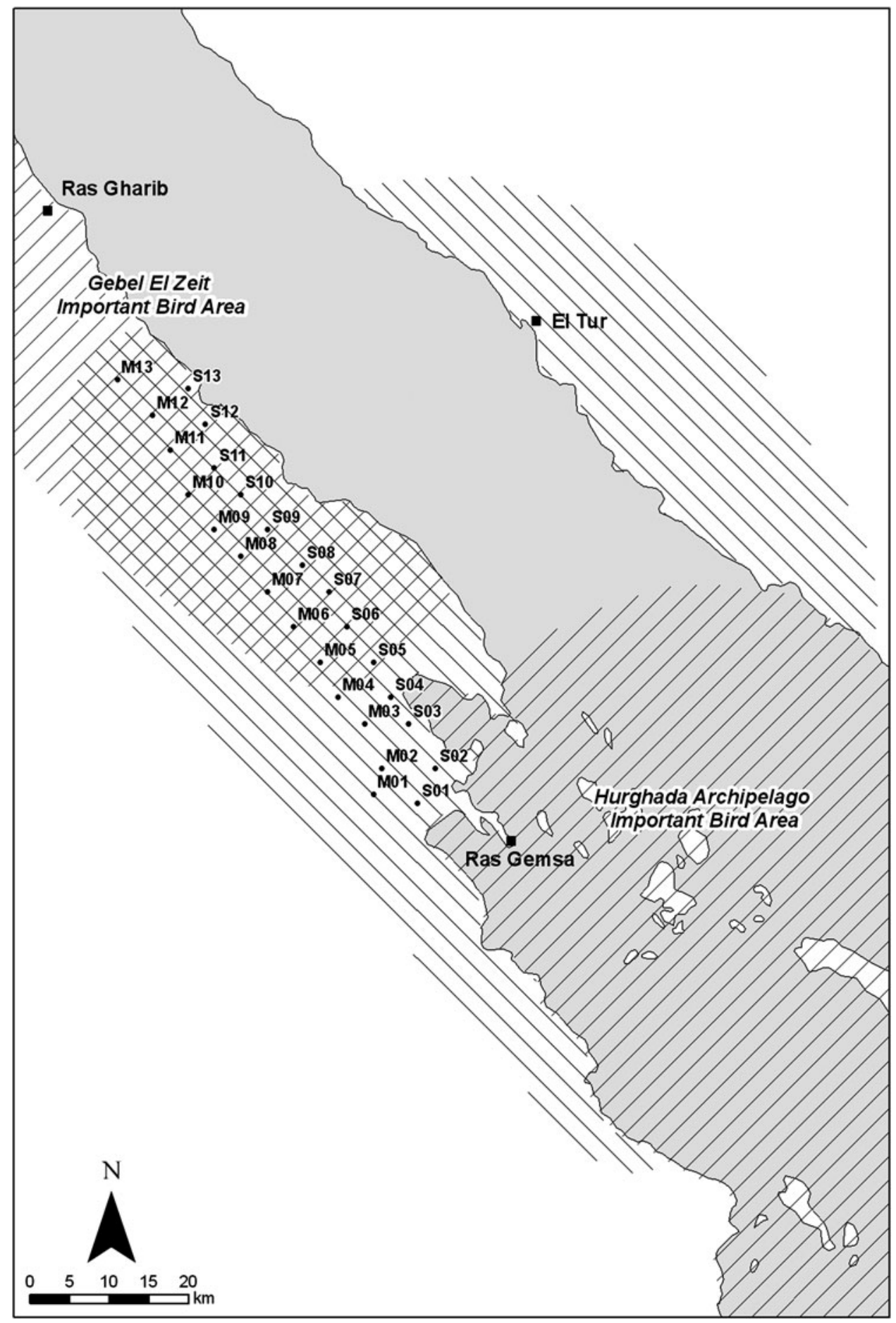

Figure 2. Suggested changes to the boundaries of the IBA 'Gebel El Zeit' and the suggestion for an additional IBA opposite Zait Bay on the other side of the Gulf of Suez (produced by BirdLife International based on IBA information in the World Bird Database and information supplied by the author). 
singly or in small groups and showed a fairly regular pattern. In contrast, storks, pelicans and cranes, migrating for the most part in enormous flocks, produced very pronounced regional fluctuations. The herons, egrets and flamingos that concentrated in the area of site $\mathrm{S}_{13}$ were attracted there by a small lake in the salt depression. The comparison between the observations inside and outside the IBA revealed that criterion AI (globally threatened species) and A4iv ( $>20,000$ raptors and storks) were also fulfilled at the sites outside the present IBA boundary. The risk to birds was similar to that in the IBA, as more than $40 \%$ entered the stratum of the first $200 \mathrm{~m}$ altitude. In view of these results, the large numbers of migrants observed to the south of the study area - often migrants are heading for Sinai at the latitude of El Gouna - and the position of the important resting site Wadi Millaha - the only wadi with fresh water - I propose an extension to the existing boundaries of the IBA to the south as suggested in Figure 2. In the north I suggest reducing the IBA to the actual area where birds cross to Sinai (Figure 2). Migrants heading for Suez concentrate mainly along the mountain ridge west of the present IBA where they should also be protected. In the north, protection of the coastal area may be needed at sites where the mountains run close to the coast. Further, it stands to reason that on the other side of the Gulf of Suez, soaring birds are no less at risk than in the study area. Even the majority of White Storks that have reached the southern tip of Sinai continue northwest along the coast of Sinai before starting the sea-crossing, thus arriving at the mainland of Egypt between Ras Gharib and Ras Gemsa (Celmins in Christensen and Jensen 2002). Therefore I suggest the designation of an IBA opposite Zait Bay on the eastern side of the Gulf of Suez (Figure 2). However, observations are needed to revise its boundaries.

Our observations revealed that migrants fly along the foothills of the Red Sea Mountains and then head for the coastal mountain chain Gebel El Zeit or the coast adjacent to the north. Especially in those species like White Stork (Creutz 1985, Schulz 1988, Goodman and Meininger 1989, Berthold et al. 2001), Levant Sparrowhawk (Grieve 1996, Baha El Din 1999) and Common Crane, substantial parts of the population cross the Gulf of Suez on a regular basis. Thus, many have no choice but to cross the study area. Others, like Lesser Spotted Eagle, a species that avoids any sea crossing (Meyburg et al. 2002, Grieve 1996), continue migration towards Suez.

\section{Acknowledgements}

I wish to thank the following ornithologists for their excellent observations during the field work: G. Pegram, J. Rauhut, A. Schreiber, D. Sturm, J. Weinbecker, I. Weiss and K. Wilson. I am grateful to U. Schleier for statistical advice, to H. Biebach and T. Roedl for support in the initial phase of the study, to T. Mebs and F. Ziesemer for advice in questions related to raptor migration, to S. Baha El Din and an anonymous referee for their constructive criticism, to R. Raiss, and K. Wilson for helpful suggestions, to A. Abdelmageed for the support in Egypt, to E. Niemann the support during the entire study and to NREA (New and Renewable Energy Authority) for permission to publish these data.

\section{References}

Alerstam, T. (1990) Bird migration. Cambridge, UK: Cambridge University Press.

Baha El Din, S. (1999) Directory of important bird areas in Egypt. Cambridge, UK: BirdLife International.

Bern Convention (1979) Convention on the Conservation of European Wildlife and Natural Habitats. Bern Switzerland: Bern Convention. 19.IX 1979. European Treaty Series No. 104.

Berthold, P., van den Bossche, W., Fiedler, W., Gorney, E., Kaatz, M., Leshem, Y. Nowak, E. and Querner, U. (2001) Der Zug des Weißstorchs (Ciconia ciconia) eine besondere Zugform auf Grund neuer Ergebnisse. J. f. Ornithologie 142: 73-92.

Creutz, G. (1985) Der Weißstorch. Wittenberg Lutherstadt: A. Ziemen Verlag.

Christensen, K. D. and Jensen, F. P. (2002) Atlas of bird migration at the Gulf of Suez, 
Egypt. Copenhagen, Denmark: Ministry of Foreign Affairs, Danida.

Dornbusch, G. (2005) Zur Bestandsentwicklung des Schwarzstorchs Ciconia nigra in Deutschland. Charadrius 41: 79-83.

Drewitt, A. L. and Langston, R. H. W. (2006) Assessing the impacts of wind farms on birds. Ibis 148: 29-42.

Gensbøl, B. and Thieme, W. (2004). Greifvoegel. München: BLV.

Goodman, S. M. and Meininger, P. L. (eds.) (1989) The birds of Egypt. Oxford: Oxford University Press.

Grieve, A. (1996) Spring raptor movements at Gebel el Zeit, Egypt. Sandgrouse 18: 61-63.

Hötker, H., Thomsen, K.-M. and Köster, H. (2004) Auswirkungen regenerativer Energiegewinnung auf die biologische Vielfalt am Beispiel der Vögel und der Fledermäuse - Fakten, Wissenslücken, Anforderungen an die Forschung, ornithologische Kriterien zum Ausbau von regenerativen Energiegewinnungsformen. Bonn: NABU Deutschland.

Langston, R. H. W. (2006) Wind, fire and water: renewable energy and birds. Proceedings of the British Ornithologists' Union annual spring conference 2005, University of Leicester, 1-3 April 2005. Ibis 148: 1-3.

Langston, R. H. W. and Pullan, J. D. (2003) Windfarms and birds: An analysis of the effects of windfarms on birds, and guidance on environmental assessment criteria and site selection issues. Cambridge, UK: BirdLife International on behalf of the Bern Convention, Strasbourg (T-PVS/Inf 12).
Leshem, Y. and Yom-Tov, Y. (1996) The magnitude and timing of migration by soaring raptors, pelicans and storks over Israel. Ibis 128: 188-203.

Mebs, T. and Schmidt, D. (2006) Die Greifvögel Europas, Nordafrikas und Vorderasiens. Biologie, Kennzeichen, Bestände. Stuttgart: Kosmos.

Meyburg, G.-U., Matthes, J. and Meyburg, C. (2002) Satellite-tracked Lesser Spotted Eagle avoids crossing water at the Gulf of Suez. Brit. Birds 95: 372-376.

Newton, I. (2008). The migration ecology of birds. Heidelberg: Academic Press as imprint of Elsevier.

Schulz, H. (1988) Weißstorchzug. Ökologie, Gefährdung und Schutz des Weißstorchs in Afrika und Nahost. Weikersheim, Germany: WWF-Umweltforschung 3.

Shirihai, H. (1996). Birds of Israel. London: Academic Press.

Shirihai, H., Reuven, Y, Alon, D., Kirwan, G. V. and Spaar, R. (2000) Raptor migration in Israel and the Middle East. A summary of 30 years of field research. Eilat, Israel: IBRC.

Spaar, R. (1995) Flight behaviour of Steppe Buzzards (Buteo buteo vulpinus) during spring migration in southern Israel: a tracking-radar study. Israel J. Zool. 41: 489-500.

Tammens, R. (2008) Spektakulärer Vogelzug über der ägyptischen Wüste. Der Falke 55: 9-13.

Wilcove, D. S. (2008). No way home. The decline of the world's great animal migration. Washington: Island Press, Shearwater Books.

\section{GUDRUN HILGERLOH}

Institute of Zoology, Johannes Gutenberg University, Johannes v. Müllerweg 6, 55128 Mainz, Germany.e-mail: gudrun.hilgerloh@t-online.de 


\section{Appendix}

Estimates of the flyway population sizes during spring migration. Numbers marked by an asterisk ${ }^{*}$ are the estimates used in this study.

\begin{tabular}{|c|c|c|}
\hline Species & Population size & Source \\
\hline $\begin{array}{l}\text { Great White Pelican Pelecanus } \\
\text { onocrotalus }\end{array}$ & $70,000-80,000$ & Shirihai (1996) \\
\hline \multirow{2}{*}{$\begin{array}{l}\text { White Stork } \\
\text { Ciconia ciconia }\end{array}$} & 500,000 & \multirow{2}{*}{$\begin{array}{l}\text { Shirihai (1996), } \\
\text { Stork-Center Bergenhusen }\end{array}$} \\
\hline & $\begin{array}{l}\text { 176,000 pairs } \\
\left(750,0^{*}\right)\end{array}$ & \\
\hline \multirow{2}{*}{$\begin{array}{l}\text { Black Stork } \\
\text { Ciconia nigra }\end{array}$} & $10,000-20,000$ & \multirow{2}{*}{$\begin{array}{l}\text { Shirihai (1996), } \\
\text { Dornbusch (2005) }\end{array}$} \\
\hline & $\begin{array}{l}9,500 \text { pairs } \\
\left(40,000^{*}\right)\end{array}$ & \\
\hline \multirow{3}{*}{$\begin{array}{l}\text { Black Kite } \\
\text { Milvus migrans } \\
\text { Egyptian Vulture } \\
\text { Neophron percnopterus }\end{array}$} & $\begin{array}{l}25,000-32,000 \\
28,000-36,000\end{array}$ & \multirow{3}{*}{$\begin{array}{l}\text { Leshem and Yom-Tov (1996) } \\
\text { Shirihai (1996) } \\
\text { Shirihai (1996), Mebs and } \\
\text { Schmidt (2006) }\end{array}$} \\
\hline & $800-1,000$ & \\
\hline & $\begin{array}{l}1,720 \text { pairs } \\
\left(5, \mathrm{OOO}^{*}\right)\end{array}$ & \\
\hline \multirow{2}{*}{$\begin{array}{l}\text { Levant Sparrowhawk } \\
\text { Accipiter brevipes }\end{array}$} & $40,000-50,000$ & \multirow{2}{*}{$\begin{array}{l}\text { Leshem and Yom-Tov (1996), } \\
\text { Mebs and Schmidt (2006), } \\
\text { Mebs pers. comm. }\end{array}$} \\
\hline & $\begin{array}{l}\text { c. } 12,000 \text { pairs } \\
\text { c. } 40,000 ?\left(60, \mathrm{OOO}^{*}\right)\end{array}$ & \\
\hline $\begin{array}{l}\text { European Honey Buzzard Pernis } \\
\text { apivorus }\end{array}$ & $190,000-850,000$ & Leshem and Yom-Tov (1996) \\
\hline $\begin{array}{l}\text { Steppe Buzzard Buteo } \\
\text { buteo vulpinus }\end{array}$ & $320,000-460,000$ & Leshem and Yom-Tov (1996) \\
\hline \multirow{3}{*}{$\begin{array}{l}\text { Long-legged Buzzard } \\
\text { Buteo rufinus }\end{array}$} & 1,816 Suez (1981) & \multirow[t]{2}{*}{ Gensbol and Thieme (2004) } \\
\hline & 4,446 Baltimi & \\
\hline & $\begin{array}{l}\text { c. } 2,900 \text { pairs } \\
\text { c. } 6,000 ?\left(6, \mathrm{OOO}^{*}\right)\end{array}$ & $\begin{array}{l}\text { Mebs and Schmidt (2006), } \\
\text { Mebs pers. comm. }\end{array}$ \\
\hline $\begin{array}{l}\text { Steppe Eagle Aquila } \\
\text { nipalensis }\end{array}$ & $11,000-75$, ooo & Leshem and Yom-Tov (1996) \\
\hline $\begin{array}{l}\text { Lesser Spotted Eagle } \\
\text { Aquila pomarina }\end{array}$ & $\begin{array}{l}83,701(1990) \\
\left(85,000^{*}\right)\end{array}$ & $\begin{array}{l}\text { Leshem and Yom-Tov (1996), } \\
\text { Shirihai et al. } 2000\end{array}$ \\
\hline $\begin{array}{l}\text { Short-toed Snake-Eagle } \\
\text { Circaetus gallicus }\end{array}$ & $7,400-12,000$ & Shirihai (1996) \\
\hline \multirow{2}{*}{$\begin{array}{l}\text { Booted Eagle } \\
\text { Hieraaetus pennatus }\end{array}$} & $800-2,000$ & \multirow{2}{*}{$\begin{array}{l}\text { Shirihai (1996), } \\
\text { Mebs and Schmidt (2006), } \\
\text { Mebs pers. comm. }\end{array}$} \\
\hline & $\begin{array}{l}\text { c. } 2,350 \text { pairs } \\
5,000 \\
\left(5,{\left.0000^{*}\right)}^{-1}\right.\end{array}$ & \\
\hline Common Crane & $5,000-10,000$ & Shirihai (1996) \\
\hline Grus grus & $\begin{array}{l}>30.000 \\
\left(50,000^{*}\right)\end{array}$ & $\begin{array}{l}\text { Total number observed at } \\
\text { Zait Bay in spring } 2007\end{array}$ \\
\hline $\begin{array}{l}\text { European Bee-eater } \\
\text { Merops apiaster }\end{array}$ & $4,000-6,300$ & Shrihai (1996) \\
\hline
\end{tabular}

